\title{
MENINGKATKAN KEMAMPUAN MEMECAHKAN MASALAH SISWA MELALUI PEMBELAJARAN PEMBERIAN TUGAS LEMBARAN KERJA SECARA KELOMPOK
}

\author{
Oleh: Yoyo Zakaria Ansori
}

Penelitian ini dilatarbelakangi rendahnya kemampuan memecahkan masalah pada siswa di sekolah dasar. Peneliti mencoba menerapkan pembelajaran dengan pemberian tugas lembaran kerja secara individual dan kelompok sebagai solusinya. Penelitian ini merupakan penelitian eksperimen dengan jumlah sampel 2 kelas yang dipilih secara acak. Sampel dibagi dengan dua perlakuan yaitu pemberian tugas secara kelompok serta pembelajaran tradisional. Data penelitian diperoleh melalui test tertulis objektif dan lembaran kerja untuk mengetahui kemampuan pemecahan masalah siswa. Hasil penelitian menunjukkan bahwa sebelum perlakuan diberikan, pengetahuan awal kedua kelas tidak berbeda secara signifikan. Setelah perlakuan diberikan, ternyata hasil belajar yang diperoleh kedua kelas terjadi peningkatan secara signifikan. Hasil belajar yang diperoleh oleh kedua kelas berbeda secara signifikan $(t=0,62)$. Dengan demikian tugas lembaran kerja secara kelompok dapat meningkatkan kemampuan pemecahan masalah siswa,

Kata kunci : Pembelajaran Pemberian Tugas Lembaran Kerja Secara Kelompok, Kemampuan Memecahkan Masalah

\section{PENDAHULUAN}

Perkembangan jaman yang semakin pesat menuntut kita untuk dapat melakukan kegiatan yang bermanfaat dalam kehidupan seharihari. Kemampuan dan keterampilan untuk dapat bertindak dan menyelesaikan suatu permasalahan harus dilatih semenjak dini (masa kanak-kanak) terutama dalam lingkungan keluarga. Kemampuan menyelesaikan masalah sendiri, mengerjakan tugasnya sendiri, dan memiliki rasa tanggungjawab merupakan suatu hal yang penting dimiliki ditanamkan pada anak sejak dini. Pada saat ini, tidak dapat dipungkiri banyak anak yang masih lalai dalam menyelesaikan pekerjaannya atau sama sekali tidak mengerjakan pekerjaan tersebut, begitu juga dengan tugas yang diberikan guru.

Menurut Sudjimat (dalam Sukasno, 2002,), belajar pemecahan masalah pada hakekatnya belajar berpikir atau belajar bernalar. Yang dimaksud dengan belajar berpikir atau belajar bernalar tersebut adalah berpikir atau bernalar dalam mengaplikasikan pengetahuanpengetahuan yang telah diperoleh sebelumnya untuk digunakan dalam memecahkan permasalahan yang belum pernah dijumpai sebelumnya.

Holmes (dalam Wardhani, dkk., 2010 : 7) menyatakan bahwa latar belakang atau alasan seseorang perlu belajar memecahkan masalah adalah adanya fakta dalam abad dua puluh satu ini bahwa orang yang mampu memecahkan masalah matematik akan hidup dengan produktif. Menurut 
Holmes, orang yang terampil memecahkan masalah akan mampu berpacu dengan kebutuhan hidupnya, menjadi pekerja yang lebih produktif, dan memahami isu-isu kompleks yang berkaitan dengan masyarakat global.

Lechner (dalam Wardhani, dkk., 2010 : 15) pada intinya menyatakan bahwa pemecahan masalah adalah proses menerapkan pengetahuan yang telah diperoleh sebelumnya ke dalam situasi baru yang belum dikenal. Sedangkan Robert Harris (dalam Wardhani, dkk., 2010:15) menyatakan bahwa memecahkan masalah adalah the management of a problem in a way that successfully meets the goal established for treating it. Atau dapat diartikan bahwa memecahkan masalah adalah pengelolaan masalah dengan suatu cara sehingga berhasil menemukan tujuan yang dikehendaki. Kemampuan memecahkan masalah tersebut seyogianya dikembangkan melalui proses pembelajaran yang dirancang dan dikembangkan secara sistematis agar tujuan ini dapat tercapai sebagai hasil yang diinginkan pada diri siswa.

Melalui sebuah pembelajaran yang dirancang dengan baik diharapkan anak dapat berkembang.Hal ini menjadi sebuah tugas guru sebagai kunci utama dalam memajukan pendidikan. Sudjana, N. (2002: 1) mengemukakan bahwa guru menempati kedudukan sentral, sebab peranannya sangat menentukan. Guru harus mampu menterjemahkan dan menjabarkan nilai-nilai yang terdapat dalam kurikulum, kemudian mentransformasikan nilai-nilai tersebut kepada siswa melalui proses pengajaran di sekolah. Menurut Hamalik, (2002: 32) bagaimanapun baiknya kurikulum, administrasi, dan fasilitas perlengkapan, kalau tidak diimbangi dengan peningkatan kualitas guru-gurunya tidak akan membawa hasil pembelajaran yang diharapkan.
Di beberapa daerah di Indonesia masih ditemukan guru yang mengajar dengan cara yang kurang menarik dan cenderung membosankan, serta kurang memberikan kesempatan kepada siswa untuk terlibat dan berpartisipasi aktif dan mengembangkan keterampilan dan pengetahuan. Kegiatan pembelajaran masih terpusat pada guru, sehingga proses belajar menjadi kaku, kurang mendukung pengembangan pengetahuan, sikap dan keterampilan siswa terutama dalam hal pemecahan masalah. Hal ini dapat berpengaruh pada prestasi belajar siswa, sebab pemecahan masalah menuntut siswa untuk terlibat dan aktif dalam mencari solusi dengan memberdayakan semua keterampilan dan pengetahuan yang dimilikinya.

Untuk mengembangkan kemampuan pemecahan masalah siswa dibutuhkan sebuah pembelajaran yang inovatif.Pembelajaran yang memberikan keterlibatan dan peran aktif siswa dalam pembelajaran.Sebuah pembelajaran yang menekankan agar siswa sendiri yang akan membangun pengetahuannya. Sehingga guru harus mampu merancang kegiatan pembelajaran bagi siswa untuk meningkatkan atau mengubah pengetahuan awalnya yang berkaitan dengan aktivitas hidup sehari-hari, di mana siswa dituntun untuk mengkonstruksi pengetahuannya sendiri. Untuk hal itu diharapkan bahwa guru tidak hanya semata-mata mentransferkan pengetahuan kepada siswa. Siswa harus membangun pengetahuan di dalam benaknya sendiri (Nur dan Wikandari. 2002:2). Masih menurut Nur dan Wikandari (2000: 2), guru dapat membantu siswa dalam mengkonstruksi pengetahuannya, dengan cara-cara mengajar yang membuat informasi 
yang diberikan oleh guru menjadi sangat bermakna dan sangat relevan bagi siswa, dan dengan memberikan kesempatan kepada siswa untuk menemukan dan menetapkan ide-ide mereka sendiri untuk belajar. Selanjutnya Nur dan Wikandari (2000), mengatakan bahwa guru dapat memberi siswa "tangga" yang dapat membantu siswa mencapai tingkat pemahaman yang lebih tinggi, namun harus diupayakan agar siswa sendiri yang memanjat "tangga" tersebut.

$$
\text { Salah satu kegiatan }
$$

pembelajaran yang memberikan keleluasaan kepada siswa untuk membangun pengetahuannya sendiri adalah dengan pemberian tugas. Salah satu alternatif ini dapat melibatkan dan membawa siswa untuk aktif. Menurut Roestiyah(2001) dengan kegiatan melaksanakan tugas siswa akan aktif belajar, dan merasa terangsang untuk meningkatkan belajar yang lebih, memupuk inisiatif dan berani bertanggungjawab sendiri, serta diharapkan siswa memiliki hasil belajar yang lebih mantap, karena siswa melaksanakan latihan-latihan selama melakukan tugas, sehingga pengalaman siswa dalam mempelajari sesuatu dapat lebih terintegrasi. Dengan demikian siswa diberi kesempatan untuk berpikir kreatif, bijaksana, serta menciptakan kejujuran.

Sebagaimana dikemukakan
oleh Sudirman(Roswita,1990)
'pemberian tugas merupakan aplikasi
prinsip pengajaran modern atau
disebut juga azas "aktivitas", dimana
guru harus merangsang siswa agar
melakukan berbagai kegiatan atau
aktivitas yang berhubungan dengan
apa yang dipelajarinya'. Jadi dalam
kegiatan belajar mengajar guru
diharapkan untuk menciptakan situasi
dan kondisi yang dapat merangsang
siswa untuk berpikir dengan cara

memberinya masalah sehari-hari yang berkaitan dengan materi pelajaran yang diajarkan. Menurut Winkel (1996) tujuan memberikan tugas kepada anak antara lain supaya siswa berlatih mengolah kembali materi pelajaran, menyusun pikirannya secara runtun, belajar membagi waktunya dengan baik, dan belajar teknik-teknik studi yang efisien dan efektif.

Metode penugasan merupakan suatu cara pemberian kesempatan kepada siswa untuk melaksanakan tugas berdasarkan petunjuk yang telah dipersiapkan guru. Tugas yang diberikan harus cukup dipahami oleh siswa sehingga mereka melaksanakan dengan penuh tanggung jawab, begitu juga tugas yang diberikan cukup jelas bagi siswa sehingga mereka tidak bertanya-tanya lagi apa yang harus dikerjakan dan apa yang menjadi tugasnya (Roestiyah, 2001). Dalam melaksanakan tugas ini siswa dapat memperoleh pengalaman secara langsung dan nyata.

Tugas dapat diberikan dalam berbagai bentuk, misalnya berupa sejumlah pertanyaan mengenai mata pelajaran, tugas tertulis atau lisan, tugas mengumpulkan sesuatu, membuat sesuatu, mengadakan observasi terhadap sesuatu dan juga bisa berupa eksperimen (Roestiyah, 2001). Memberi tugas dengan membawa anak ke lokasi yang menjadi sumber belajar berarti kita memberikan kesempatan kepada siswa untuk mengadakan observasi dan menemukan sendiri apa yang menjadi permasalahan serta mampu membuat laporan baik tertulis ataupun lisan.

Tugas dapat diberikan secara kelompok atau perorangan. Melalui metode ini dapat mengembangkan berbagai keterampilan dan 
pembiasaan untuk mandiri dan bersikap jujur (Aqib, 2002). Tugas yang diberikan dapat secara paralel atau komplementer, tugas paralel berarti semua tugas sama sedangkan komplementer tugas saling melengkapi pemecahan masalah (Dimyati dan Mudjiono, 2002).

\section{METODE PENELITIAN}

Penelitian ini merupakan penelitian eksperimen dengan teknik analisis data yang diolah secara kuantitatif. Penelitian ekperimen menurut Arikunto (1993 : 272), yaitu merupakan penelitian yang dimaksudkan untuk mengetahui ada tidaknya akibat dari "sesuatu" yang dikenakan pada subjek selidik dan mencoba meneliti ada tidaknya hubungan sebab akibat. Dengan demikian, tujuan dari metode penelitian ini adalah untuk mengetahui kemampuan pemecahan masalah akibat dari suatu pengajaran IPS dengan menggunakan dua pendekatan pembelajaran yang berbeda, yaitu pendekatan pembelajaran dengan pemberian tugas lembar kerja dan tradisional.
Populasi yang terlibat dalam penelitian adalah seluruh siswa kelas VSD sekecamatan Majalengka. Adapun sampel dalam penelitian ini adalah siswa kelas V SDN Cijati. Penentuan sampel untuk kelas eksperimen dan kelas kontrol dilakukan secara acak kelas. Dalam penelitian ini, sampel penelitian kelas eksperimen adalah kelas VC dan kelas kontrol VB, yang masing-masing terdiri dari 30 orang siswa.

\section{HASIL PENELITIAN}

Setelah dilakukan pengolahan data dengan menggunakan program komputer SPSS, maka dapat diperoleh hasil pretes pada kelas eksperimen dan kelas kontrol, setelah dianalisis kedua kelompok tersebut, diperoleh nilai tertinggi, nilai terendah, nilai ratarata, dan standar deviasi selengkapnya disajikan pada Tabel berikut ini:

\section{Tabel 1}

Nilai Tertinggi, NilaiTerendah, Nilai

Rata-rata, dan Standar Deviasi

Pretes Kemampuan Pemecahan Masalah

\begin{tabular}{|c|c|c|c|c|c|c|c|c|}
\hline Pada penelitian ini ada Nifua & \multicolumn{4}{|c|}{ Kelas Eksperimen } & \multicolumn{4}{|c|}{ Kelas Kontrol } \\
\hline ak menurut kelas untuk diteliti, yait & $x_{\min }$ & $x_{\text {maks }}$ & $\bar{x}$ & sd & $x_{\min }$ & $x_{\text {maks }}$ & $\bar{x}$ & sd \\
\hline $\begin{array}{l}\text { kelompok percobaan I (kelompok } \\
\text { eksperimen) dan kelompok }{ }^{\text {II }}\end{array}$ & 1,4 & 3,8 & 2,32 & 0,6157 & 1,4 & 3,9 & 2,50 & 0,6664 \\
\hline
\end{tabular}

(kelompok kontrol). Ketompok percobaan I memperoleh perlakuan berupa pembelajaran IPS dengan pembelajaran pemberian tugas lembar kerja secara kelompok, sedangkan kelompok kontrol menggunakan pembelajaran secara tradisional. Sebelum perlakuan, kedua kelompok diberi tes pengetahuan penunjang dan pretes, kemudian setelah kedua kelompok diberikan perlakuan maka masing-masing kelompok diadakan postes.

Dari tabel di atas secara deskriptif kemampuan awal pemecahan masalah siswa pada kedua kelas relatif sama. Pada kelas eksperimen rata-rata hasil tes sebesar 2,32 sedangkan pada kelas kontrol 2,50.

Setelah dilakukan uji normalitas dan homogenitas terhadap nilai pretes kelas eksperimen dan kontrol, ternyata kedua kelas berdistribusi normal dan homogen, selanjutnya dilakukan pengujian perbedaan rata-rata nilai hasil pretes dengan menggunakan uji-t pada taraf 
signifikansi $\alpha=0.05$ (uji dua pihak, $1 / 2 \alpha$ $=0.025)$ dengan kriteria pengujian: $\mathrm{H}_{0}$ diterima jika $-\mathrm{t}_{\text {tabel }}<\mathrm{t}_{\text {hitung }}<+\mathrm{t}_{\text {tabel }}$, sedangkan pada keadaan lain $\mathrm{H}_{0}$ ditolak.

Tabel 2

Uji Perbedaan Rata-Rata Pretes Kelas Eksperimen dan Kelas Kontrol
Berdasarkan Tabel di atas diperoleh $t_{\text {hitung }}$ $=8,157$ tidak berada pada interval -1.672 s/d +1.672, maka dapat disimpulkan bahwa kemampuan pemecahan masalah siswa kedua kelas (kelas eksperimen dan kontrol) berbeda secara signifikan.

\section{KESIMPULAN}

Terdapat perbedaan kemampuan pemecahan masalah yang signifikan

\begin{tabular}{|c|c|c|c|c|c|c|c|}
\hline \multicolumn{3}{|c|}{ Kel. Eksperimen } & \multicolumn{3}{|c|}{ Kel. Kontrol } & \multirow[b]{2}{*}{$\mathrm{t}_{\text {hitung }}$} & \multirow[b]{2}{*}{$\mathrm{t}_{\text {tabel }}$} \\
\hline$\overline{x_{e}}$ & $\mathrm{~S}_{\mathrm{e}}$ & $\mathrm{se}_{\mathrm{e}}^{2}$ & $x_{k}$ & $S_{k}$ & $\mathrm{~s}_{\mathrm{k}}^{2}$ & & \\
\hline 323 & 0,616 & 0,379 & 2,500 & 0,666 & 0,444 & 1,073 & 1,672 \\
\hline
\end{tabular}

Berdasarkan Tabel di atas diperoleh $t_{\text {hitung }}$ $=1,073$ berada pada interval $-1.672 \mathrm{~s} / \mathrm{d}$ $+1.672\left(t_{\text {tabel }}<t_{\text {hitung }}<+t_{\text {tabel }}\right)$, maka dapat disimpulkan bahwa kemampuan pemecahan masalah siswa kedua kelas (kelas eksperimen dan kontrol) relatif sama atau tidak terdapat perbedaan.

Untuk hasil postes kemampuan pemecahan masalah secara deskriptif disajikan pada tabel di bawah ini:

Tabel 3

Nilai Tertinggi, NilaiTerendah, Nilai Rata-rata, dan Standar Deviasi

Postes Kemampuan Pemecahan Masalah
Kesinantlana siswa yang memperoleh TidaRegabetajaran pemberian tugas perbdeimalaran kerja

secara kelompokdengan siswa yang memperoleh pembelajaran tradisional. Dengan demikian pembelajaran pemberian tugas lembaran kerja secara kelompok dapat meningkatkan kemampuan memecahkan masalah siswa seklah dasar.

\section{DAFTAR PUSTAKA}

Aqib, Z. (2002). Profesionalisme Guru Dalam Pembelajaran. Surabaya:Insan Cendekia.

Dimyati dan Mudjiono. (2002). Belajar dan Pembelajaran. Jakarta: Rineka Cipta.

\begin{tabular}{|c|c|c|c|c|c|c|c|c|}
\hline \multirow{2}{*}{$\begin{array}{c}\text { Nilai } \\
\text { Maks }\end{array}$} & \multicolumn{4}{|c|}{ Kelas Eksperimen } & \multicolumn{4}{c|}{ Kelas Kontrol Roswita } \\
\cline { 2 - 9 } & $x_{\text {min }}$ & $x_{\text {maks }}$ & $\bar{x}$ & sd & $x_{\text {min }}$ & $x_{\text {maks }}$ & $\bar{x}$ & sd \\
\hline 6,0 & 3,6 & 5,2 & 4,27 & 0,4856 & 2,2 & 4,7 & 3,4 & 0,5585 \\
\hline
\end{tabular}

W. (1990). Perbedaan Hasil Belajar Siswa dengan Pola Merangkum dan Soal Pada Pokok Bahasan Metabolisme Kelas IIA2. Skripsi - UNRI.

Berdasarkan data pada tabel di atas terlihat bahwa hasil postes kemampuan pemecahan masalah pada kelas berbeda. Rata-rata postes kelas eksperimen sebesar 4,27 sedangkan pada kontrol sebesar 3,40.

Tabel 4

Uji Perbedaan Rata-Rata Pretes Kelas Eksperimen dan Kelas Kontrol
Roestiyah. (2001). Strategi Belajar Mengajar. Jakarta: Rineka Cipta.

Ruseffendi, ET (1991). Pengantar Kepada Membantu Guru Mengembangkan

Kompetensinya dalam Pengajaran Matematika untuk Meningkatkan CBSA. Bandung : Tarsito.

\begin{tabular}{|c|c|c|c|c|c|c|c|c|}
\hline \multicolumn{3}{|c|}{ Kel. Eksperimen } & \multicolumn{3}{|c|}{ Kel. Kontrol } & \multirow[b]{2}{*}{$\mathrm{t}_{\text {hitung }}$} & \multirow[b]{2}{*}{$t_{\text {tabel }}$} & \multirow{2}{*}{$\begin{array}{l}\text { Kestudjan } \\
\text { pulan }\end{array}$} \\
\hline$\overline{x_{e}}$ & $\mathrm{~S}_{\mathrm{e}}$ & $\mathrm{s}_{\mathrm{e}}^{2}$ & $x_{k}$ & $s_{k}$ & $s_{k}^{2}$ & & & \\
\hline 4,27 & 0,616 & 0,379 & 3,40 & 0,666 & 0,444 & 8,157 & 1,672 & $\begin{array}{c}\text { Ada } \\
\text { perbedaan }\end{array}$ \\
\hline
\end{tabular}

H.D., (2000), Strategi Pembelajaran, Bandung, Falah Production. 
Sudjana, N. (1989). Dasar-Dasar Proses Belajar Mengajar. Bandung; Sinar Baru.

Sudjana, N. (1992). Metoda Statistika. Bandung; Tarsito.

Sudjana, N. (1995). Penilaian Hasil dan Proses Belajar Mengajar. Bandung; Sinar Baru.
Wardhani, dkk. 2010. Pembelajaran Kemampuan Pemecahan Masalah Matematika di SD. Jakarta: Kemdiknas.

Winkel, W.S. (1996). Psikologi Pengajaran. Jakarta:Grasindo. 